\title{
Proposal That Spirochaeta stenostrepta Zuelzer Replace Spirochaeta plicatilis Ehrenberg as the Type Species of the Genus Spirochaeta Ehrenberg Request for an Opinion
}

\author{
E. CANALE-PAROLA \\ Department of Microbiology, University of Massachusetts, Amherst, Massachusetts 01003 \\ It is proposed that Spirochaeta stenostrepta Zuelzer replace Spirochaeta \\ plicatilis Ehrenberg as the type species of the genus Spirochaeta Ehrenberg.
}

The Approved Lists of Bacterial Names were published recently under the editorship of Skerman et al. on behalf of the Ad Hoc Committee of the Judicial Commission of the International Committee on Systematic Bacteriology (11). The editors of the Lists pointed out that type strains were not available for some of the names of the species included on the Lists. However, in some instances these names were retained on the Lists to preserve the status of genera "... which contained well described species for which representative strains were available for all but the Type Species of the genus itself" (11). The hope was expressed by the editors that "... early action will be taken to request the Judicial Commission to conserve these genera with new Type Species" (11).

A type species that has been retained on the Approved Lists, and for which representative strains are not available, is Spirochaeta plicatilis Ehrenberg. This bacterium was originally described and named in 1835 (7), and it has been observed by various authors in $\mathrm{H}_{2} \mathrm{~S}$-containing mud $(1,13)$. In spite of its early description, $S$. plicatilis has never been isolated in pure culture. A bacterium that was identified as $S$. plicatilis was isolated by Dyar (6), but later this organism was shown to be a species of Saprospira $(10,12)$.

In accordance with the above-mentioned suggestion made by the editors of the Approved Lists, I propose that $S$. plicatilis Ehrenberg no longer be recognized as the type species of the genus Spirochaeta inasmuch as representative strains of this species are not available. In place of $S$. plicatilis Ehrenberg, I recommend that Spirochaeta stenostrepta Zuelzer be assigned the status of type species. Among all species of Spirochaeta for which representative strains are available $(2,4,11), S$. stenostrepta Zuelzer is chronologically the first to have been validly named and described (13).

Strains of S. stenostrepta have been isolated and studied extensively $(3,5,8,9)$. A description of this species has been published in Bergey's Manual of Determinative Bacteriology (2), and a culture of the type strain has been deposited with the American Type Culture Collection (ATCC) under the number 25083.

In summary, it is respectfully requested that the Judicial Commission issue an opinion recognizing Spirochaeta stenostrepta Zuelzer as the new type species of the genus Spirochaeta Ehrenberg. The type strain of $S$. stenostrepta is ATCC 25083. A description of this strain has been published (2).

\section{REPRINT REQUESTS}

Address reprint requests to: Dr. E. Canale-Parola, Department of Microbiology, University of Massachusetts, Amherst, MA 01003.

\section{LTERATURE CITED}

1. Blakemore, R. P., and E. Canale-Parola. 1973. Morphological and ecological characteristics of Spirochaeta plicatilis. Arch. Mikrobiol. 89:273-289.

2. Buchanan, R. E., and N. E. Gibbons (ed.). 1974. Bergey's manual of determinative bacteriology, 8 th ed. The Williams and Wilkins Co., Baltimore.

3. Canale-Parola, E. 1977. Physiology and evolution of spirochetes. Bacteriol. Rev. 41:181-204.

4. Canale-Parola, E. 1980. Revival of the names Spirochaeta litoralis, Spirochaeta zuelzerae, and Spirochaeta aurantia. Int. J. Syst. Bacteriol. 30:594.

5. Canale-Parola, E., Z. Udris, and M. Mandel. 1968. The classification of free-living spirochetes. Arch. Mikrobiol. 63:385-397.

6. Dyar, M. T. 1947. Isolation and cytological study of a free-living spirochete. J. Bacteriol. 54:483-493.

7. Ehrenberg, C. G. 1835. Dritter Beitrag zur Erkenntnis grosser Organisation in der Richtung des kleinsten Raumes. Abh. Akad. Wiss. Math. Berlin, p. 143-336.

8. Hespell, R. B., and E. Canale-Parola. 1970. Carbohydrate metabolism in Spirochaeta stenostrepta. J. Bacteriol. 103:216-226.

9. Holt, S. C., and E. Canale-Parola. 1968. Fine structure of Spirochaeta stenostrepta, a free-living, anaerobic spirochete. J. Bacteriol. 96:822-835.

10. Lewin, R. A. 1962. Saprospira grandis Gross; and sug- 
gestions for reclassifying helical apochlorotic gliding organisms. Can. J. Microbiol. 8:555-563.

11. Skerman, V. B. D., V. McGowan, and P. H. A. Sneath (ed.). 1980. Approved lists of bacterial names. Int. J. Syst. Bacteriol. 30:225-420.

12. Starr, M. P., and V. B. D. Skerman. 1965. Bacterial diversity: the natural history of selected morphologically unusual bacteria. Annu. Rev. Microbiol. 19:407454.

13. Zuelzer, M. 1912. Über Spirochaeta plicatilis Ehrbg. und deren Verwandtschaftsbeziehungen. Arch. Protistenkd. 24:1-59. 